\title{
The Medieval World on the Renaissance Stage
}

\section{Meadhbh O'Halloran}

School of English , UCC

"I know the present only through the television screen, whereas I have direct knowledge of the Middle Ages". (Umberto Eco)

\section{Introduction}

Christopher Marlowe (1564-1593) was an Elizabethan playwright, poet and translator, and also an exact contemporary of William Shakespeare. Marlowe was the first to develop the blank verse format for which Shakespeare would become famous. Marlowe's promising career abruptly ended with his sudden, violent death at the age of 29. Soon after, Shakespeare achieved his first successes on the London stage. Understandably, Marlowe's work has often been considered in relation to his famous successor, and many conspiracy theories propose that Shakespeare was Marlowe. In the popular 1998 film Shakespeare in Love, Shakespeare gets his best lines from Marlowe, and this is how Marlowe is perceived: as Shakespeare's predecessor and influence, with his own work a secondary consideration. My thesis aims to shift the focus back onto Marlowe's canon. When his work is studied in its own right, Marlowe 's influences are classical texts and contemporary humanist discourse. Instead of studying what developed from Marlowe, or his contemporary influences, I examine Marlowe's use of earlier material: medieval literature.

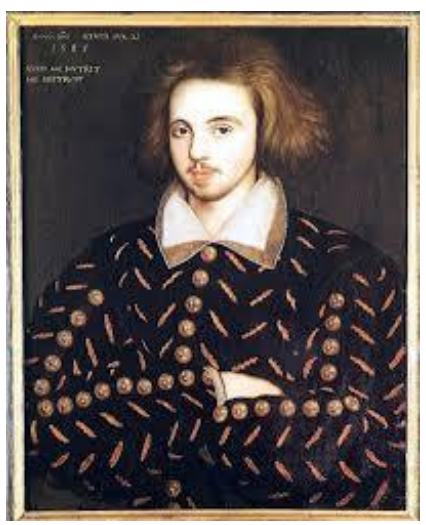

Figure 1: A portrait thought to be of Marlowe. Commons licensed image from http:// commons.wikimedia.org/wiki/File:Christopher_Marlowe.jpg 


\section{What exactly is "medieval" literature?}

No era has consistently captured the imagination like the medieval period. From Lord of the Rings to Game of Thrones, we often see the medieval world re-imagined in the contemporary image. This long tradition of depicting the Middle Ages began immediately after its end, in the Renaissance or early modern period. Marlowe's society held a continued fascination with their recent past. The "medieval" period is open to debate, generally it is classified as the "middle" period between the late antique period and the Renaissance, circa 800-1400 A.D. The term "Medieval literature" encompasses a wide spectrum of material, not just literary tales but plays, oral tales, historical texts and learned manuscripts on various topics. Most of these texts such as history plays, courtly romance tales and religious theatre, remained familiar to every section of the population. Tales still familiar in the twenty-first century such as Robin Hood were extant, alongside similar heroic such as Bevis of Hampton, Guy of Warwick and Huon of Bordeaux. What is significant about these tales was their multi-genre format: they appeared in various forms of print, from expensive hard-bound tale collections to cheap pamphlets, in plays and in songs. As large sections of the population remained illiterate, oral readings were commonplace. These tales circulated throughout English society, and formed part of the shared consciousness of the population. Though the Elizabethan era was an extremely innovative period for English drama, these medieval formats reappeared on the stage. English theatre began as religious performance to embellish church services, but developed into a shared cultural experience. Marlowe's hometown of Canterbury was a hub of street theatre throughout his early years, and travelling "chapmen" sold cheap storybooks throughout the country.

\section{Medieval narrative in the Early Modern Era}

What is remarkable about the survival of medieval literary forms in Marlowe's lifetime is the fact they survived at all. Literary trends are products of social change, and the greatest upheaval occurred in the post-Reformation period. The Reformation affected not only religious matters but every aspect of society. As Queen Elizabeth sought to establish a Protestant kingdom, any reference to Catholicism was outlawed. As many popular tales pertained to the adventures of Catholic saints, whole swathes of literature became taboo. Publications underwent strict censorship, as every text was required to promote the new Protestant ideology. Literature was not simply utilised as a source of entertainment, but for instruction of the reader in appropriate behaviour. The new Protestant church sought to encourage, and enforce, conformity wherever possible.

Within the Universities, medieval literature was also under attack. Humanist scholars claimed a "rediscovery" of the classical past, and sought to emphasise their own innovations by denouncing popular literature as frivolous and crude. Yet old habits die hard and the general population continued to read their favourite familiar stories in their increasingly unstable world. 
Unsurprisingly, religious drama was also outlawed. This left a considerable gap in the cultural life of the country. Theatre moved from civic to commercial, where previously performances were funded by guilds and aristocratic patrons, now they were produced by private enterprises for a paying audience. It was in this new industry that Marlowe would make his name.

A playwright could expect a potential audience to have a shared understanding of an array of plots, stock characters and literary forms. Just as satirists rely on their audience's prior knowledge, a common understanding between author and audience can be utilised in the creation of new material.

\section{Marlowe's Re-Imagining of Medieval Literature}

In the immediate post-Reformation period, readers and audiences expected the narratives they would encounter to uphold religious and social norms. Although contemporary writers denied the omnipresence of medieval tropes and themes in the early modern period, it is this very pervasiveness that renders medieval literature ripe for re-invention. Marlowe re-imagines medieval forms by redefining them. He reworks medieval history in Edward II to destabilise the audience's belief in the concept of the divine right of kings. In his play The Jew of Malta Marlowe presents an apparently stereotypical villain, only to use the stock medieval characteristics to invite the audience to sympathise with the Jew. Marlowe sets up generic expectations only to flout them. This creates a disorientating effect which encourages his audience to think critically and question, rather than blindly accept, the status quo. During an era of strict censorship, subtly displacing the expectations of the audience allows Marlowe to probe established belief systems from a safe distance.

\section{Conclusion}

Medieval literary tropes and themes retained their currency in early modern England, and were continuously used by authors. Marlowe's use of the earlier material is unique and challenging to his audience, encouraging free-thinking during a period of major religious, political and social upheval. In essence, my research will identify Marlowe's use of medieval literary material and demonstrate the importance of this within Marlowe's literary corpus. Marlowe scholarship suffers from an over-emphasis on his most accomplished play, Doctor Faustus, and has been dominated by biographical readings of his work which examine a literary figure first, and his work second. My thesis serves to redress this balance, it is an entirely new reading of Marlowe's work which moves away from these well-trodden paths. It illustrates the enduring and important legacy of medieval literature in later periods, and offers a new reading of a canonical author, and a more nuanced conception of the period that produced such innovative drama.

With thanks to my supervisors Dr. Edel Semple, Dr. Andrew King and Prof. Lee Jenkins. My research is generously supported by a School of English Postgraduate Studentship. 